\title{
Influence of Bamboo Shoot Powder Supplementation on Chemical and Functional Characteristics of Pasta
}

\author{
Vanlalliani*, Anju K. Dhiman and Surekha Attri \\ Department of Food Science and Technology, Dr YS Parmar University of Horticulture and \\ Forestry, Nauni, Solan - 173230, Himachal Pradesh, India \\ *Corresponding author
}

\section{A B S T R A C T}

Bamboos are plants belonging to the sub-family Bambusoidae of Poaceae grown mainly in the mixed deciduous and tropical evergreen areas of Asia, Africa, the Caribbean and Latin America. They are becoming one of the preferred food items among the people all

\section{Keywords}

Bamboo powder, Pasta, Fortification, Quality

\section{Article Info}

Accepted:

04 July 2019

Available Online:

10 August 2019 over the world. Latest advancement proves bamboo shoot as a functional food due to the presence of biochemical components like dietary fibre, polyphenols and sterols. Therefore, there exists a great opportunity especially, for utilization in food products as therapeutic agent. The bamboo powder prepared from the shoots of Dendrocalamus hamiltoniiwas evaluated for chemical and functional characteristics and used for incorporation in pasta. Bamboo shoot powder was analyzed for moisture, ash, fat, protein, total dietary fibre, total carbohydrates, energy value, hydrogen cyanide and water holding capacity. The bamboo shoot powder was incorporated at $0 \%$ (Pasta with $100 \%$ semolina), 2, 4, 6, 8 and $10 \%$ level by substituting semolina. The prepared pasta with different treatments was evaluated for various quality attributes. Variations were detected in ash, total dietary fibre, total carbohydrates and water holding capacity from 0.68 to $2.05 \%, 3.87$ to $4.67 \%, 74.59$ to $77.04 \%$ and 0.884 to $1.412 \mathrm{~mL} / \mathrm{g}$, respectively. Results showed that up to $8 \%$ level of fortification with bamboo shoot powder, the pasta was acceptable with improved functional and nutraceutical properties compared to the control pasta.

\section{Introduction}

Bamboo is one of the fastest growing plants with the ability to survive in a wide range of climatic and soil conditions. The most commonly grown edible bamboo species in India are Bambuspallida, B. tulda, B.polymorpha, B.balcooa, Dendrocalamus hamiltonii, D.giganteus and Melocanna bambusoides (Choudhury et al., 2012 and Chauhan et al., 2016). Some species with special highlight for the industrial processing are Bambusa, Dendrocalamus, Phyllostachys, Pseudosasa, Sasa and Sinoarundinaria (Manhães, 2008 and Pereira and Beraldo, 2016). Bamboo is recognized as nutraceutical (Xuhe, 2003; Lo et al., 2008 and Chongtham et al., 2011) because of its rich composition in phytosterols and high fibre content. The bamboo shoots have functional properties such as weight reduction, prevention of constipation and bowl cancer and reduction of cholesterol level. Consumer interest in wholesome/nutritious foods and beverages 
continues, and one category with potential for fast growth is foodstuff fortified with fibre. Previously referred to as roughage, bulk, or ballast, fibre is now termed dietary fibre. Theyare a potential ingredient in a healthy diet and have positive connection with human health.

Food fortification is a mean of overcoming micronutrient deficiency of some foods. It is also used to enrich some kind of foods by incorporation of nutritionally rich entities. Foods tobe fortified are chosen in a way that it is commonly and regularly used by the target consumers. But during fortification, it should also strictly be kept in mind that the sensorial characteristics of the food are not hampered much, or it may not be acceptable to the consumers (Akhtar et al., 2008).

Pasta products (Macaroni, spaghetti, vermicelli) means the product obtained from suji or maida with or without addition of ingredients like edible groundnut flour, tapioca flour, soya flour, milk powder, spices, vitamins, minerals, by kneading the dough and extending it (FSSAI, 2011). It shall be free from added colour, dirt, insects' larvae and impurities or any other extraneous matter. It shall conform to the following standards: Moisture - Not more than 12.50 per cent, total ash - not more than 1.00 per cent on dry basis, ash insoluble in dilute $\mathrm{HCl}$ (on dry basis) - not more than 0.10 per cent. The addition of fibres into pasta formulations can be of great importance to produce a widely consumed functional staple food with nutrition importance and relatively high-fibre content to help fill the gap between fibre recommendations and current intakes.

\section{Materials and Methods}

The bamboo shoots of Dendrocalamus hamiltonii specie was procured from Anu, Giripul, Karganu, Lakothi, and Nauni villages of District Solan, in Himachal Pradesh, India. Semolina was purchased from local market. The packaging material such as Low Density Polyethylene (LDPE) pouches was purchased from International Scientific and Surgicals, Solan.

\section{Preparation of bamboo shoot powder}

The bamboo shoot of Dendrocalamus hamiltonii was used for preparation of powder. The shoot with sheath was washed to remove any adhering dirt, dust or any other foreign material. The sheath was removed for extraction of tender shoot. The bamboo shoots were cut into thin slices. The fresh shoots contain hydrogen cyanide (HCN), a toxic substance which needs to be removed prior to use for edible purposes. The method described by Dhiman et al., (2017) was followed to remove $\mathrm{HCN}$ from fresh bamboo shoots. The bamboo shoot slices were soaked in water for 24 hours. These slices were then boiled for 90 minutes. The water was drained and the slices were allowed to cool down at room temperature. The bamboo shoot slices were dried in a mechanical dehydrator at $60 \pm 2{ }^{\circ} \mathrm{C}$ for 5 hours i.e. until it reached equilibrium moisture content. The slices were converted into powder with the help of a grinder. The powder was passed through a sieve of 36 mesh size and stored in polyethylene pouches with proper sealing until further use (Fig. 1).

\section{Preparation of pasta}

The pasta was prepared by using $200 \mathrm{~g}$ of semolina and $95 \mathrm{~mL}$ of water. A total of six treatments of pasta were prepared, each of a batch of $200 \mathrm{~g}$ semolina. While one sample was kept as control having only $200 \mathrm{~g}$ semolina, and in the other five samples, the semolina was replaced with bamboo shoot powder at a level of 2, 4, 6, 8 and $10 \%$. The weighed quantity of semolina was sieved and fed into the mixing chamber of Kent Noodle 
and Pasta Maker from the top. The lid of the appliance was closed and plugged in. The 'Auto' (automatic mode) key was pressed to start the appliance. The water was added in the right proportion after turning on the appliance. The mixing time was standardized (6-8 minutes) to ensure proper mixing. The pastas were extruded through a die to obtain pipe rigate shape and manually cut into $2 \mathrm{~cm}$ length. The extruded pasta was dried in a mechanical dehydrator at $60 \pm 2{ }^{\circ} \mathrm{C}$ for about 5 hours or till its weight became constant (Fig. 2).

\section{Chemical and functional characteristics of pasta}

Moisture, ash, and crude protein content were determined according to the standard AOAC (2012) methods. Fat was determined using the method described by Ranganna (2009). Total carbohydrates content was calculated by differential method (AOAC, 2006) and expressed in percentage. The total dietary fibre was determined by AOAC (2016) method. The water holding capacity was analyzed by the method described by Sosulski et al., (1976).

\section{Sensory analysis of pasta}

The pasta with different treatments was subjected to sensory evaluation (9-point hedonic scale) following standard procedure described by Ranganna (2009).

Ten judges comprising of faculty members and post graduate students of the department of Food Science and Technology, Dr YS Parmar University of Horticulture and Forestry, Nauni, Solan (HP) were selected to evaluate the products.

The parameters considered for the evaluation were appearance, texture, aroma, taste and overall acceptability.

\section{Statistical analysis}

Data on chemical and functional characteristics of bamboo shoot powder and pasta was analysed by Completely Randomized Design (CRD) suggested by Cochran and Cox (1967). While Randomised Complete Block Design (RBD) as described by Mahony (1985) was used to analyze the data pertaining to sensory evaluation. The experiment for recipe standardization and storage studies was replicated three times.

\section{Results and Discussion}

\section{Chemical and functional characteristics of bamboo shoot powder}

The proximate composition of bamboo powder prepared from the shoots of Dendrocalamus hamiltoniiis shown in Table 1. The data revealed that bamboo shoot powder was rich in crude protein, ash, total dietary fibre, total carbohydrates, energy value, antioxidant activity, water holding capacity and very low in crude fat. The hydrogen cyanide content was also found to be in the safe limit for human consumption. All these quality attributes make the bamboo shoot powder an ideal food. The total dietary fibre and crude protein content of the bamboo shoot powder was found to be $20.34 \%$ and $10.49 \%$, respectively. The high content of protein and total dietary fibre in bamboo shoot powder made it a suitable ingredient for nutritional supplementation in food.

\section{Chemical and functional characteristics of different treatments of pasta}

The data on chemical and functional characteristics of different treatments of pasta $\left(\mathrm{T}_{1}, \mathrm{~T}_{2}, \mathrm{~T}_{3}, \mathrm{~T}_{4}, \mathrm{~T}_{5}\right.$ and $\left.\mathrm{T}_{6}\right)$ are shown in Table 2. The moisture content decreased from 11.58 in $\mathrm{T}_{1}$ to $9.26 \%$ in $\mathrm{T}_{6}(10 \%$ level of incorporation) and ash content varied from 
0.68 in $\mathrm{T}_{1}$ to $2.05 \%$ in $10 \%$ bamboo shoot powder supplemented pasta (Fig. 3). With increased level of substitution, the fat and protein content also decreased from 0.97 to $0.63 \%$ and 12.18 to $11.02 \%$, respectively. On the other hand, total dietary fibre, total carbohydrates and water holding capacity increased from 3.87 to $4.67 \%, 74.59$ to 77.04 $\%$ and 0.884 to $1.412 \mathrm{~mL} / \mathrm{g}$, respectively with an increase in level of incorporation of bamboo shoot powder to $10 \%$. Baddi (2012) have also recorded that macaroni supplemented with 10 per cent dietary fibre extracted from mango peel powder had higher dietary fibre, but lower protein, fat and carbohydrate contents than the control samples. Addition of 1.5 per cent chickpea flour in pasta increased the total dietary fibre content by 48 per cent in relation to a control pasta sample containing only semolina (Fares \& Menga, 2012). Padalino et al., (2013) developed a spaghetti enriched with pea flour and reported that the addition of 1.50 per cent pea flour contributed to a significant increase in the total dietary fibre (7.50\%) compared to the control sample $(4.55 \%)$, representing an increase of 65 per cent in fibre content. This diff erence in the increase in the total dietary fibre content of pastas is related to the chemical nature of the fibre added. Many studies show that some fruit by-products are superior sources of dietary fibres compared to vegetables and cereals (Elleuch et al., 2011). Oladunmoye et al., (2014) reported similar decreasing trend in fat and protein contents as level of wheat replacement increased. Monterio et al., (2016) have noticed an increase in fat, protein and ash percentage, while moisture and carbohydrate decreased with increase in level (23\%) of incorporation of tilapia flour in pasta. Crizel et al., (2015) have also noticed a significant increase in total dietary fibre content (3.7 to $7.5 \%)$ and ash content $(0.68$ to $0.80 \%)$ in pasta after incorporation of $7.5 \%$ of orange fibre in pasta while protein and carbohydrates decreased. According to Brazilian normative (Brasil, 1998), foods can be considered as asource of fibre if the products have at least $3 \mathrm{~g}$ of fibre/100 gsample, and foods with a "high fibre" content have $6 \mathrm{~g} / 100$ gsample. Therefore, the pasta with $4.67 \mathrm{~g} / 100 \mathrm{~g}$ bamboo fibre can be considered to be a good source of fibre.

Table.1 Chemical and functional characteristics of bamboo shoot powder

\begin{tabular}{|l|c|}
\hline Characteristics & Bamboo shoot powder (Mean \pm SD) \\
\hline Chemical characteristics & $4.78 \pm 0.07$ \\
\hline Moisture (\%) & $16.12 \pm 0.06$ \\
\hline Ash (\%) & $0.18 \pm 0.08$ \\
\hline Crude fat (\%) & $10.49 \pm 0.06$ \\
\hline Crude protein (\%) & $20.34 \pm 0.07$ \\
\hline Total dietary fibre (\%) & $68.43 \pm 0.07$ \\
\hline Total carbohydrates (\%) & $235.94 \pm 0.05$ \\
\hline Energy value (Kcal) & $13.06 \pm 0.05$ \\
\hline Hydrogen cyanide (mg/100 g) & $65.24 \pm 0.06$ \\
\hline Antioxidant capacity (\%) & \\
\hline Functional characteristics & $10.67 \pm 0.06$ \\
\hline Water holding capacity (mL/g) & \\
\hline
\end{tabular}


Table.2 Analysis of bamboo shoot powder supplemented pasta

\begin{tabular}{|l|l|l|l|l|l|l|c|}
\hline Treatment & $\begin{array}{l}\text { Moistur } \\
\text { e }\end{array}$ & $\begin{array}{l}\text { Ash } \\
(\mathbf{\%})\end{array}$ & $\begin{array}{l}\text { Fat } \\
(\mathbf{\%})\end{array}$ & $\begin{array}{l}\text { Protein } \\
(\mathbf{\%})\end{array}$ & $\begin{array}{l}\text { Total } \\
\text { dietary } \\
\text { fibre } \mathbf{( \% )}\end{array}$ & $\begin{array}{l}\text { Total } \\
\text { carbohydrates } \\
(\boldsymbol{\%})\end{array}$ & $\begin{array}{l}\text { Water holding } \\
\text { capacity (mL/g) }\end{array}$ \\
\hline $\mathbf{T}_{\mathbf{1}}(\mathbf{1 0 0 : 0 )}$ & 11.58 & 0.68 & 0.97 & 12.18 & 3.87 & 74.59 & 0.884 \\
\hline $\mathbf{T}_{\mathbf{2}}(\mathbf{9 8 : 2 )}$ & 11.21 & 0.92 & 0.81 & 11.43 & 3.98 & 75.63 & 0.903 \\
\hline $\mathbf{T}_{\mathbf{3}} \mathbf{( 9 6 : 4 )}$ & 10.86 & 1.16 & 0.75 & 11.39 & 4.16 & 75.84 & 1.013 \\
\hline $\mathbf{T}_{\mathbf{4}}(\mathbf{9 4 : 6 )}$ & 10.65 & 1.44 & 0.72 & 11.22 & 4.27 & 75.97 & 1.141 \\
\hline $\mathbf{T}_{\mathbf{5}}(\mathbf{9 2 : 8 )}$ & 9.94 & 1.65 & 0.66 & 11.18 & 4.39 & 76.57 & 1.271 \\
\hline $\mathbf{T}_{\mathbf{6}}(\mathbf{9 0 : 1 0})$ & 9.26 & 2.05 & 0.63 & 11.02 & 4.67 & 77.04 & 1.412 \\
\hline
\end{tabular}

Table.3 Sensory analysis of different treatments of pasta

\begin{tabular}{|c|c|c|c|c|c|}
\hline Treatments & Appearance & Texture & Aroma & Taste & Overall acceptability \\
\hline $\mathbf{T}_{\mathbf{1}}(\mathbf{1 0 0 : 0})$ & 7.76 & 7.64 & 7.59 & 7.83 & 7.79 \\
\hline $\mathbf{T}_{\mathbf{2}}(\mathbf{9 8 : 2})$ & 7.82 & 7.71 & 7.66 & 7.87 & 7.85 \\
\hline $\mathbf{T}_{\mathbf{3}}(\mathbf{9 6 : 4 )}$ & 7.89 & 7.79 & 7.76 & 7.94 & 7.90 \\
\hline $\mathbf{T}_{\mathbf{4}}(\mathbf{9 4 : 6 )}$ & 7.93 & 7.87 & 7.84 & 8.06 & 8.03 \\
\hline $\mathbf{T}_{\mathbf{5}}(\mathbf{9 2 : 8 )}$ & 8.17 & 8.09 & 7.96 & 8.21 & 8.26 \\
\hline $\mathbf{T}_{\mathbf{6}}(\mathbf{9 0 : 1 0})$ & 8.06 & 7.94 & 7.87 & 8.13 & 8.11 \\
\hline $\mathbf{C D}_{\mathbf{0 . 0 5}}$ & $\mathbf{0 . 1 2}$ & $\mathbf{0 . 0 9}$ & $\mathbf{0 . 1 2}$ & $\mathbf{0 . 0 5}$ & $\mathbf{0 . 0 4}$ \\
\hline
\end{tabular}

Fig.1 Bamboo powder prepared from D. hamiltonii shoots

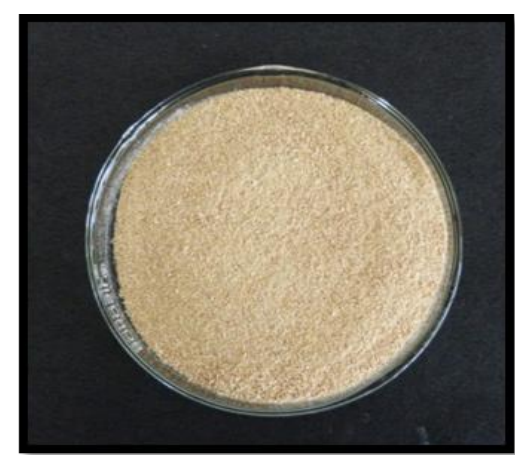

Fig.2 Pasta (100\% Semolina)
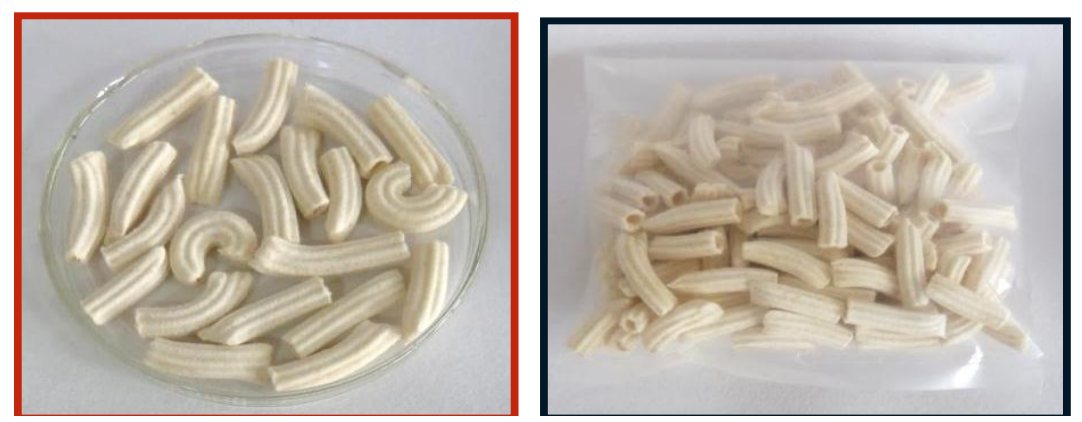
Fig.3 Pasta (8\% Bamboo shoot powder)

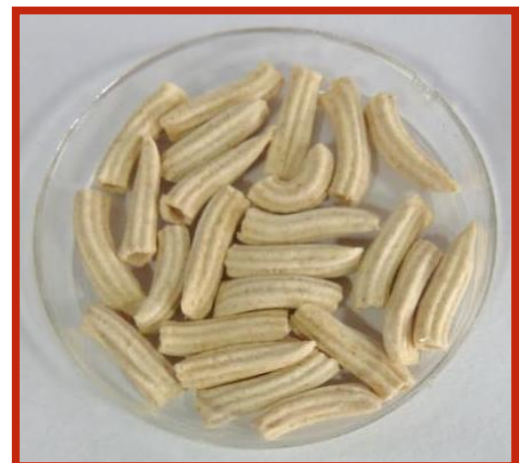

Sensory analysis of different treatments of pasta

Sensory analysis results for all six treatments of pasta are given in Table 3. The appearance of pasta was acceptable till $8 \%$ level of incorporation of bamboo shoot powder. With increased level of incorporation of bamboo shoot powder, the appearance of pasta became darker and had low scored low. The texture was also found to be acceptable till $8 \%$ incorporation as higher level of incorporation of bamboo shoot powder resulted in breakage of pasta. And as for aroma, level of incorporation beyond $8 \%$ was not acceptable. The taste of pasta above $8 \%$ level of bamboo shoot powder incorporation was not acceptable by the judges. It may be because of slight bitterness that is present in raw bamboo shoots due to high polyphonel content. The overall acceptability of pasta with $8 \%$ level of incorporation had the highest score among the six treatments. In view of the appearance, texture, aroma, taste and overall acceptability, pasta of acceptable quality can be prepared using $8 \%$ of bamboo shoot powder supplementation.

Bamboo shoot powder is rich in minerals, total dietary fibre, total carbohydrates and water holding capacity. Therefore, pasta enriched with bamboo shoot powder showed higher ash, and total dietary fibre than the control sample. It may be concluded from the study that bamboo shoot powder could be incorporated up to a level of $10 \%$ in the formulation of pasta

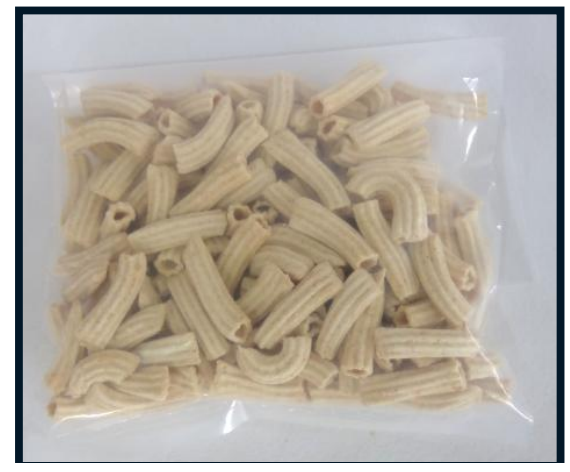

without affecting the overall quality. At $10 \%$ level of bamboo shoot powder incorporation, the pasta had moisture content of $9.26 \%$, ash content of $2.05 \%$, fat content of $0.63 \%$, protein content of $11.02 \%$, total dietary fibre content of $4.67 \%$, total carbohydrates of $77.04 \%$ and water holding capacity of $1.412 \mathrm{~mL} / \mathrm{g}$. Thus, bamboo shoot can be utilized for preparation of fibre rich pasta with improved functional properties.

\section{References}

Akhtar S, Anjum FM, Rehman SU, Sheikh MA and Farzana K. 2008. Effectof fortification on physico-chemical and microbiological stability of whole wheat flour. Food Chemistry 110:113-119.

AOAC. (2012). Official methods of analysis of AOAC International (19th ed.), Association of Official Analytical Chemists, Gaithersburg, M.D. USA

AOAC. (2016). Official methods of analysis of AOAC International (20th ed.), Association of Official Analytical Chemists, Gaithersburg, M.D. USA

AOAC. 2006. Official methods of analysis (18th ed), Association of Official Analytical Chemists, Gaithersburg, M.D. USA

Baddi J. 2012. Extraction of total polyphenols and dietary fibre from mango peel and its application in selected food products. M. Sc Thesis. Department of Food Science and Nutrition, University of Agricultural Sciences, GKVK, Bengaluru-560065. 146p. Brasil. Agência Nacional de Vigilância Sanitária - 
ANVISA. 1998. Portaria $\mathrm{n}^{\circ} 27$, de 13 de janeiro de 1998. Aprova o Regulamento Técnicoreferente à Informação Nutricional Complementar

(declaraçõesrelacionadasaoconteúdo de nutrientes). Diário Oficial da União. Retrieved from http://www.anvisa.gov.br/elegis

Chauhan OP, Unni LE, Kallepalli C, Pakalapati SR and Batra HV. 2016. Bamboo shoots: composition, nutritional value, therapeutic role and product development for value addition. International Journal of Food Fermentation Technology 6:1-12.

Chongtham N, Bisht MS and Haorongbam S. 2011. Nutritional properties of bamboo shoots: potential and prospects for utilization as a health food. Comprehensive Reviews in Food Science and Food Safety 10:153-168.

Choudhury D, Sahu JK and Sharma G.D. 2012. Value addition to bamboo shoots: a review. Journal of Food Science and Technology 49:407-414.

Cochran WG and Cox CM. 1967. Experimental Design. John Wiley and Sons, New York. pp. 171-217.

Crizel TM, Rids AD, Thys RCS, Flôres SH. 2015. Effects of orange by-product fber incorporation on the functional and technological properties of pasta.Food Science and Technology 35:546-551

DhimanAnju K, Synrem M, Attri S and Verma AK. 2017. Food value of underexploited Himalayan bamboos: development of pickles and their quality evaluation during storage. Indian Food Packer 115-128.

Elleuch M, Bedigian D, Roiseux, O, Besbes, S, Blecker C and Attia H. 2011. Dietary fibers and fibre-rich by-products of food processing: characterization, technological functionality and commercial applications: a review. Food Chemistry 124:411-421.

Fares C and Menga V. 2012. Effects of toasting on the carbohydrate profile and antioxidant properties of chickpea (Cicer arietinum L.) flour added to durum wheat pasta. Food Chemistry 131:1140-1148.

Lo TY, Cui HZ, Tang PWC and Leung HC. 2008. Strength analysis of bamboo by microscopic investigation of bamboofibre. Construction and Building Materials 22: 1532-1535.

Mahony MO. 1985.Sensory evaluation of food. In: Statistical Methods and Procedures. Marcel Dekker Inc., New York.

Manhães AP. 2008. Caracterização da cadeiaprodutiva do bambu no Brasil: abordagempreliminar. Monografia Seropédica: Universidade Federal Rural do Rio de Janeiro.

Monteiro MLG, Marsico ET, Soares MS, Magalhaes AO. Canto ACVCS, CostaLima BRC, Alvares TS, Conte CA. 2016. Nutritional profile and chemical stability of pasta fortified with tilapia (Oreochromnis niloticus) flour. Plus One 11:1-17.

Padalino L, Mastromatteo M, Lecce L, Spinelli S, Conto F and Del Nobile MA. 2013. Chemical composition, sensory and cooking quality evaluation of durum wheat spaghetti enriched with pea flour. International Journal of Food Science and Technology 49: 1544-1556.

Pereira MAR and Beraldo AL. 2016. Bambu de corpo e alma (2nd ed.). Bauru/SP: Canal 6.

Ranganna S. 2009. Handbook of Analysis and Quality Control for Fruit and Vegetable Products.Tata McGraw Hill, New Delhi. 1112p.

Sosulski FW, Garatt MO and Slinkard AE. 1976. Functional properties of ten legume flours. International Journal of Food Science of Technology 9: 66-74.

Xuhe C. 2003. Promotion of bamboo for poverty alleviation and economic development. Journal of Bamboo and Rattan 2: 345-350.

\section{How to cite this article:}

Vanlalliani, Anju K. Dhiman and Surekha Attri. 2019. Influence of Bamboo Shoot Powder Supplementation on Chemical and Functional Characteristics of Pasta. Int.J.Curr.Microbiol.App.Sci. 8(08): 148-154. doi: https://doi.org/10.20546/ijcmas.2019.808.018 